\title{
ARTICIE Effect of Buckwheat (Fagopyrum esculentum) Powder on the Physicochemical and Sensory Properties of Emulsion-type Sausage
}

\section{OPEN ACCESS}

\section{Received July 5, 2018 \\ Revised July 29, 2018 \\ Accepted July 30, 2018}

*Corresponding author: Hack-Youn Kim Department of Animal Resources Science, Kongju National University, Yesan 32439, Korea

Tel: + 82-41-330-1241

Fax: +82-41-330-1249

E-mail: kimhy@kongju.ac.kr

Juhui Choe

Department of Agricultural Biotechnology, Center for Food and Bioconvergence, and Research Institute of Agriculture and Life Science, Seoul National University, Seoul 08826, Korea

Tel: +82-2-880-4820

Fax: $+82-2-873-2271$

E-mail: jhjhchoe@snu.ac.kr

${ }^{\dagger, *}$ These authors contributed equally to this work as joint $\operatorname{first}\left({ }^{\dagger}\right)$ or corresponding $\left({ }^{*}\right)$ author

\author{
Sol-Hee Lee ${ }^{1,{ }^{\dagger}}$, Gye-Woong Kim ${ }^{1,+}$, Juhui Choe ${ }^{2,{ }^{*}}$, and Hack-Youn Kim ${ }^{1,{ }^{*}}$ \\ ${ }^{1}$ Department of Animal Resources Science, Kongju National University, Yesan 32439, \\ Korea \\ ${ }^{2}$ Department of Agricultural Biotechnology, Center for Food and Bioconvergence, \\ and Research Institute of Agriculture and Life Science, Seoul National University, \\ Seoul 08826, Korea
}

\begin{abstract}
Various amounts of buckwheat powder $(0 \%, 1 \%, 2 \%$, and $3 \%)$ were added to emulsion-type pork sausages. The effects of buckwheat powder on the physicochemical characteristics of the emulsion type sausages, including proximate composition, cooking yield, viscosity, $\mathrm{pH}$, instrumental color, texture profile analysis (TPA), and sensory evaluation, were determined. Increased levels of added buckwheat powder led to higher moisture $(p<0.05)$, ash content $(p<0.05$ or $>0.05)$, and cooking yield $(p<0.05)$. However, the protein and fat contents of the sausage samples were lower $(\mathrm{p}<0.05)$ with higher levels of added buckwheat powder. The instrumental color and $\mathrm{pH}$ values were affected by the addition of buckwheat powder, which has a $\mathrm{pH}$ of 6.1 and associated color coordinates of $\mathrm{L}^{*}=75.0, \mathrm{a}^{*}=1.3$, and $\mathrm{b}^{*}=8.7$. Meat batter with $3 \%$ buckwheat powder was shown the highest $(\mathrm{p}<0.05)$ viscosity indicating great formation of emulsion. There were no significant differences in the TPA among the treated samples. The viscosity value increased with increasing cooking yield in the batter $\left(r^{2}=0.7283\right)$ i.e. the correlation coefficient between the two measurements was very high and positive. For sensory traits except for tenderness, the highest scores $(\mathrm{p}<0.05)$ was detected on sausages with $3 \%$ added buckwheat powder by a panel. These results suggest that the addition of 3\% buckwheat powder to emulsion-type sausages produces a more beneficial meat product, with a lower fat content, greater formation of emulsion and no adverse effects on sensory properties.
\end{abstract}

Keywords buckwheat, dietary fiber, physicochemical property, emulsion, sausage

\section{Introduction}

Over the past few decades, consumers' health concerns have increased leading to growth in the health food and nutraceuticals markets (Sun, 2008; Utama et al., 2018). In the muscle food sector, the demand for healthy meat products, including low-fat, low-calorie, low-salt, and functional ingredient-added (e.g. fiber-fortified) meat products have also increased (Olmedilla-Alonso et al., 2013).

(C) Korean Society for Food Science of Animal Resources. This is an open access article distributed under the terms of the Creative Commons Attribution Non-Commercial License (http://creativecommons.org/licences/by-nc/3.0) which permits unrestricted non-commercial use, distribution, and reproduction in any medium, provided the original work is properly cited. 
The intake of dietary fiber-rich foods reduces the incidence of conditions such as obesity, cardiovascular, and coronary heart disease (Johnson and Southgate 1994; Lairon et al., 2005; Pereira et al., 2004). In meat products, fiber plays an important role that enhances cooking yield and emulsion stability due to its water and fat binding abilities, as well as its textural properties (Choe et al., 2013; Cofrades et al., 2000). A number of studies have reported that the addition of fiber sources, including grains, vegetables, and plants, improves the functional properties various of meat products (Kim, 2013; Kim and Kim, 2017; Lee et al., 2008; Mansour and Khalil, 1997).

Buckwheat (Fagopyrum esculentum) contains 30\% total dietary fiber (approximately 26.5\% insoluble and 3.0\% soluble dietary fiber), significant levels of essential amino acids, polyunsaturated fatty acids, and vitamins B and E (Lee et al., 1995; Lin et al., 2009). In addition, buckwheat possesses functional properties that include anti-oxidant, anti-inflammatory, and anti-carcinogenic properties due to the high levels of rutin and other flavonoids that are key components of buckwheat (Baumgertel et al., 2003; Lin et al., 2009). In particular, the anti-obesity properties of buckwheat are well known to reduce low-density lipoprotein (LDL) and cholesterol levels (Choy et al., 2013). However, to the best of our knowledge, only a limited number of studies on the application of buckwheat as a functional material in meat products have been published (Bejosano and Corke, 1998). Therefore, the objective of this study was to determine the effect of buckwheat powder on the physicochemical characteristics of sausages including proximate composition, $\mathrm{pH}$ values, instrumental color, cooking yield, viscosity, texture profile analysis (TPA), and sensory evaluation.

\section{Materials and Methods}

\section{Preparation of sausage samples with buckwheat powder}

Ham (M. semitendinosus and M. semimembranosus) muscle from fresh pork and back fat were purchased from a local market (Hongjumeat, Chungnam, Korea), $48 \mathrm{~h}$ postmortem. The subcutaneous and intramuscular fat and visible connective tissue were removed from the fresh ham muscle. The sausages were produced to the following formulation: $50 \%$ pork meat, $30 \%$ pork back fat, $20 \%$ ice, $1.2 \%$ nitrite pickled salt (salt:nitrite $=99.4: 0.6$ ), ground $1 \%$ sugar, $0.6 \%$ mixed spice, and buckwheat powder [0 (control), 1, 2, and 3\%, respectively]. The sausage manufacture for three batches was performed in the different days. For each batch, lean pork meat and fat were ground through a 3-mm ground plate (PA-82, Mainca, Spain). The fat and additives were emulsified using a bowl cutter (K-30, Talsa, Spain). In addition, buckwheat powder was added to all samples, excluding the control. The meat batter was stuffed into natural casings and the meat samples were cooked in a chamber $\left(10.10 \mathrm{ESI} / \mathrm{SK}\right.$, Alto Shaam, USA) at $85 \pm 1^{\circ} \mathrm{C}$ until their core temperatures reached $75^{\circ} \mathrm{C}$. The cooked sausages were rested at $10^{\circ} \mathrm{C}$ for $30 \mathrm{~min}$ and then stored at $5^{\circ} \mathrm{C}$ until analyzed.

\section{Proximate composition}

The proximate composition of each sample was analyzed according to the AOAC (2012) standard. Moisture content (AOAC method 950.46B) was determined by weight loss after $12 \mathrm{~h}$ at $105^{\circ} \mathrm{C}$ in a drying oven (SW-90D, Sang Woo Scientific Co., Bucheon, Korea). Fat content (AOAC method 960.69) was determined by the Soxhlet method using a solvent extraction system (Soxtec ${ }^{\circledR}$ Avanti 2050 Auto System, Foss Tecator AB, Sweden), and protein content (AOAC method 981.10) was determined with an automatic Kjeldahl nitrogen analyzer (Kjeltec ${ }^{\circledR} 2300$ Analyzer Unit, Foss Tecator AB, Sweden). Ash was determined using a muffle furnace according to AOAC method 920.153. 


\section{Cooking yield}

Cooking yield was determined for individual samples by calculating the weight before and after cooking as follows:

Cooking yield $(\%)=\frac{\text { Weight of cooked meat batter }(\mathrm{g})}{\text { Weight of uncooked meat batter }(\mathrm{g})} \times 100$

\section{Viscosity}

Meat batter viscosity was measured in triplicate with a rotational viscometer (MerlinVR, Rheosys, USA) at $20 \mathrm{rpm}$. A 2.0 $\mathrm{mm}$ gap was set between the $30 \mathrm{~mm}$ parallel plates that were then rotated at a constant shear rate $\left(\mathrm{s}^{-1}\right)$ for $60 \mathrm{~s}$ prior to each reading to give apparent viscosity $(\mathrm{cP})$. The temperature of each sample $\left(25 \pm 1^{\circ} \mathrm{C}\right)$ during testing was also recorded.

pH

Homogenates were prepared using $4 \mathrm{~g}$ meat samples and distilled water $(16 \mathrm{~mL})$. The $\mathrm{pH}$ of each homogenate was measured with a pH meter (Model S220, Mettler-Toledo, Switzerland). All measurements were performed in triplicate.

\section{Color}

The color of uncooked and cooked meat samples were determined using a colorimeter (CR-10, Minolta, Tokyo, Japan; illuminate $\mathrm{C}$, calibrated with a white plate, CIE $\mathrm{L}^{*}=+97.83, \mathrm{CIE} \mathrm{a}^{*}=-0.43, \mathrm{CIE} \mathrm{b}^{*}=+1.98$ ). Lightness (CIE $\mathrm{L}^{*}$ value), redness (CIE a* value), and yellowness (CIE b* value) values were recorded.

\section{Texture profile analysis (TPA)}

TPA was performed in triplicate for each sample at room temperature using a texture analyzer (TA 1, Lloyd Co., USA). Samples $(\varnothing 25 \times 50 \mathrm{~mm})$ were cut from the central region of each sausage. Prior to analysis, each sample was allowed to equilibrate to room temperature $\left(25^{\circ} \mathrm{C}, 1 \mathrm{~h}\right)$. The TPA conditions were as follows: pre-test speed, $2.0 \mathrm{~mm} / \mathrm{s}$; post-test speed, $5.0 \mathrm{~mm} / \mathrm{s}$; maximum load, $2 \mathrm{~kg}$; head speed, $2.0 \mathrm{~mm} / \mathrm{s}$; distance, $8.0 \mathrm{~mm}$; and force, $5.0 \mathrm{~g}$. TPA values were measured using a cylinder probe $(\varnothing 25 \mathrm{~mm})$ and were calculated from force and time plots. Values of hardness $(\mathrm{kg})$, springiness, cohesiveness, gumminess $(\mathrm{kg})$, and chewiness $(\mathrm{kg})$ were determined for each sample.

\section{Sensory evaluation}

A semi-trained group of ten panelists were engaged to evaluate the sensory qualities of each sausage sample in terms of color, flavor, tenderness, juiciness, and overall acceptability. Sausage samples were cooked to a core temperature of $75^{\circ} \mathrm{C}$ in a water bath (Model 10-101, Dae Han Co., Korea), cooled, cut into quarters (Ø 25×20 mm), and served randomly to the panelists. Panelists were instructed to cleanse their palates between samples with water. The color (1=extremely undesirable, $10=$ extremely desirable), flavor $(1=$ extremely undesirable, $10=$ extremely desirable $)$, tenderness $(1=$ extremely tough, $10=$ extremely tender), juiciness ( $1=$ extremely dry, 10=extremely juicy), and overall acceptability (1=extremely undesirable, $10=$ extremely desirable) of the cooked sausage samples were evaluated using a ten-point descriptive scale.

\section{Statistical analysis}

All analyses were conducted at least three times under each set of experimental conditions, and the mean value \pm standard 
deviation of each parameter were determined. Variance analyses were performed on all the measured variables using the general linear model (GLM) procedure within the SAS statistical package (SAS, 2011). Duncan's multiple range test $(p<0.05)$ was used to determine statistical differences among the treatment means. The procedure CORR of the SAS package was used to calculate correlations between viscosity and cooking yield.

\section{Results and Discussion}

\section{Proximate composition, $\mathrm{pH}$ and color}

The proximate compositions of sausages depending on the levels of added buckwheat powder are shown in (Table 1). While the moisture contents of the sausage samples were numerically increased with increasing levels of added buckwheat powder, sausages sample with $3 \%$ added buckwheat powder was the highest moisture content $(p<0.05)$. Significant decreases in the protein $(p<0.05)$ and fat $(p<0.05)$ contents of the sausage samples were observed with increasing levels of added buckwheat powder, while the sausages sample with $3 \%$ added buckwheat powder presented the highest $(\mathrm{p}<0.05)$ ash content among the treated samples. These results are attributable to the high dietary fiber content of buckwheat powder that led to high moisture and ash, and low protein and fat contents in the sausage samples. Shin et al. (2017) reported that moisture contents of the emulsion-type chicken sausage samples were dramatically increased with increasing levels of added buckwheat powder. Grain powders such as buckwheat, black rice powder and red rice powder improved water holding capacity between meat proteins and water molecular (Park and Kim, 2016; Shin et al., 2017). In this study, the addition of buckwheat powder caused an increase in moisture content and resulted in a relative decrease in protein and fat content.

The $\mathrm{pH}$ and color in the uncooked and cooked sausage samples were dependent on the levels of added buckwheat powder (Table 2). The $\mathrm{pH}$ values of the sausages increased significantly with increasing levels of added buckwheat powder, irrespective of cooking, which is due to the $\mathrm{pH}$ of buckwheat powder (6.1). Shin et al. (2017) observed that the addition of buckwheat powder to chicken sausages presented a higher $\mathrm{pH}$ than the control, which was due to the high $\mathrm{pH}$ of the buckwheat powder. In both uncooked and cooked sausage samples, the addition of 3\% buckwheat powder resulted in the highest $\mathrm{L}^{*}$ and $\mathrm{b}^{*}$ values. However, interestingly, the opposite trend was observed for $\mathrm{a}^{*}$; increasing the levels of added buckwheat powder led to significantly higher $\mathrm{a}^{*}$ values in uncooked sausages and lower values in cooked samples. These color results are attributable to the color of buckwheat powder ( $\mathrm{L}^{*}: 75.0, \mathrm{a}^{*}: 1.3$, and $\left.\mathrm{b}^{*}: 8.7\right)$. Similar results were reported by Choi and Chung (2007). Shin et al. (2017) reported that redness of chicken sausage showed a increasing tendency as the amount of added buckwheat powder increased.

Table 1. Proximate composition of pork emulsion-type sausage formulated with various levels of buckwheat powder

\begin{tabular}{ccccc}
\hline \multirow{2}{*}{ Traits } & \multicolumn{3}{c}{ Buckwheat powder (\%) } \\
\cline { 2 - 5 } & 0 (control) & 1 & 2 & 3 \\
Moisture & $44.75 \pm 0.33^{\mathrm{c}}$ & $46.77 \pm 0.43^{\mathrm{b}}$ & $47.95 \pm 0.59^{\mathrm{b}}$ & $50.33 \pm 0.61^{\mathrm{a}}$ \\
Protein & $22.19 \pm 0.26^{\mathrm{a}}$ & $19.26 \pm 0.49^{\mathrm{b}}$ & $17.25 \pm 0.67^{\mathrm{c}}$ & $16.40 \pm 0.45^{\mathrm{c}}$ \\
Fat & $25.75 \pm 0.36^{\mathrm{a}}$ & $23.27 \pm 0.15^{\mathrm{b}}$ & $20.08 \pm 1.52^{\mathrm{c}}$ & $18.75 \pm 0.17^{\mathrm{d}}$ \\
Ash & $1.97 \pm 0.06^{\mathrm{b}}$ & $2.07 \pm 0.05^{\mathrm{b}}$ & $2.03 \pm 0.07^{\mathrm{b}}$ & $2.22 \pm 0.06^{\mathrm{a}}$ \\
\hline
\end{tabular}

All values are mean \pm SD.

${ }^{a-d}$ Means in the same row with different letters are significantly different $(p<0.05)$. 
Table 2. pH and color of pork emulsion-type sausage formulated with various levels of buckwheat powder

\begin{tabular}{|c|c|c|c|c|c|c|}
\hline \multirow{2}{*}{ Traits } & & & \multicolumn{4}{|c|}{ Buckwheat powder (\%) } \\
\hline & & & 0 (control) & 1 & 2 & 3 \\
\hline \multirow{2}{*}{$\mathrm{pH}$} & & Uncooked & $5.67 \pm 0.01^{\mathrm{d}}$ & $5.72 \pm 0.01^{\mathrm{c}}$ & $5.79 \pm 0.01^{b}$ & $5.85 \pm 0.01^{\mathrm{a}}$ \\
\hline & & Cooked & $5.84 \pm 0.02^{\mathrm{d}}$ & $5.90 \pm 0.01^{\mathrm{c}}$ & $5.96 \pm 0.01^{b}$ & $6.00 \pm 0.01^{\mathrm{a}}$ \\
\hline \multirow{6}{*}{ Color } & Uncooked & CIE L* & $69.43 \pm 0.33^{\mathrm{c}}$ & $71.07 \pm 0.60^{b}$ & $72.50 \pm 1.21^{\mathrm{ab}}$ & $72.73 \pm 1.06^{\mathrm{a}}$ \\
\hline & & CIE $a^{*}$ & $6.20 \pm 0.14^{\mathrm{d}}$ & $6.77 \pm 0.06^{\mathrm{c}}$ & $7.15 \pm 0.21^{\mathrm{b}}$ & $7.53 \pm 0.31^{\mathrm{a}}$ \\
\hline & & CIE $b^{*}$ & $17.60 \pm 0.29^{\mathrm{c}}$ & $18.53 \pm 0.38^{b}$ & $18.87 \pm 0.25^{\mathrm{ab}}$ & $19.30 \pm 0.42^{\mathrm{a}}$ \\
\hline & Cooked & CIE L* & $69.67 \pm 0.64^{\mathrm{c}}$ & $70.83 \pm 0.47^{b}$ & $70.73 \pm 0.50^{\mathrm{ab}}$ & $71.70 \pm 0.30^{\mathrm{a}}$ \\
\hline & & CIE $a^{*}$ & $7.28 \pm 0.46^{\mathrm{a}}$ & $6.93 \pm 0.22^{\mathrm{ab}}$ & $6.53 \pm 0.21^{\mathrm{b}}$ & $6.40 \pm 0.44^{\mathrm{b}}$ \\
\hline & & CIE $b^{*}$ & $15.03 \pm 0.45^{\mathrm{c}}$ & $15.63 \pm 0.06^{\mathrm{bc}}$ & $16.33 \pm 0.57^{\mathrm{ab}}$ & $16.75 \pm 0.39^{a}$ \\
\hline
\end{tabular}

All values are mean $\pm \mathrm{SD}$.

${ }^{\mathrm{a}-\mathrm{d}}$ Means in the same row with different letters are significantly different $(\mathrm{p}<0.05)$.

\section{Cooking yield and viscosity}

The cooking yields of the sausage samples were affected by the added buckwheat powder ( $<<0.05 ;$ Fig. 1 ). According to Lee and Sohn (1994), this observation is caused by the water-binding ability of fiber. Many authors reported that the addition of dietary fiber s, such as rice bran, black rice, and isolated soy bean led to increases in cooking yield by enhancing the waterholding capacity and protein-binding ability of the meat (Choe et al., 2011; Steenblock et al., 2001).

The viscosity of emulsified meat mince is closely related to its fat and water retaining capacity (Choe et al., 2011). As depicted in Fig. 2, higher levels of added buckwheat powder resulted in higher initial viscosities of the sausage samples $(p<0.05)$. The sausage samples devoid of buckwheat powder exhibited the lowest initial (108.1 Pa.s) and final (58.9 Pa.s) viscosities. Among the treated samples, the highest final viscosity $(\mathrm{p}<0.05)$ was observed for the sausage sample containing $3 \%$ added buckwheat powder. This result is attributable to the fact that buckwheat-powder dietary fiber increases water retention in meat emulsions. Kim et al. (2009) reported that higher amounts of added wheat fiber and isolated soybean powder led to increases in viscosity and emulsion stability of emulsion-type sausages, resulting in decreases in cooking loss. Overall, improvements in the cooking yields and viscosities of emulsified meat products will help producing stable sausages.

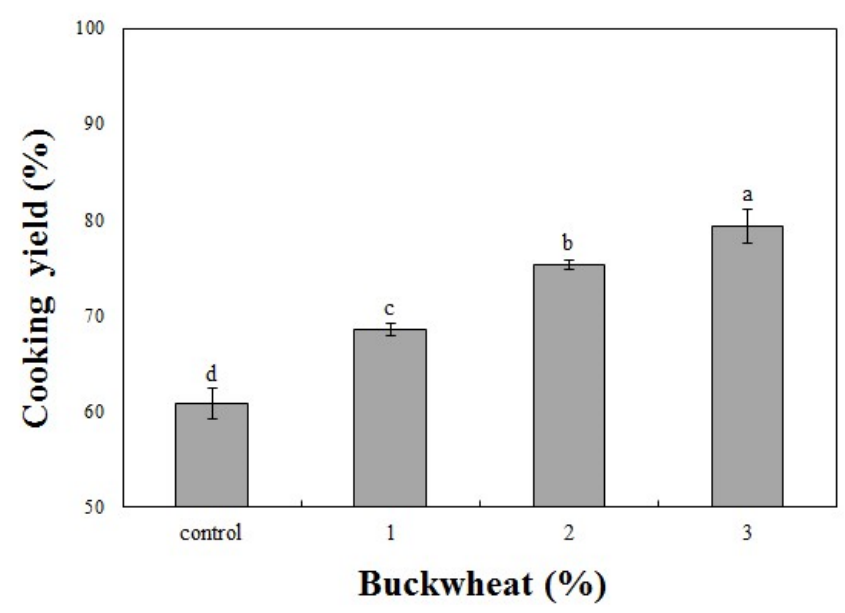

Fig. 1. Cooking yield of pork emulsion-type sausage formulated with various levels of buckwheat powder. Error bars mean standard deviation of the mean. ${ }^{a-d}$ Means with different letters are significantly different $(p<0.05)$. 


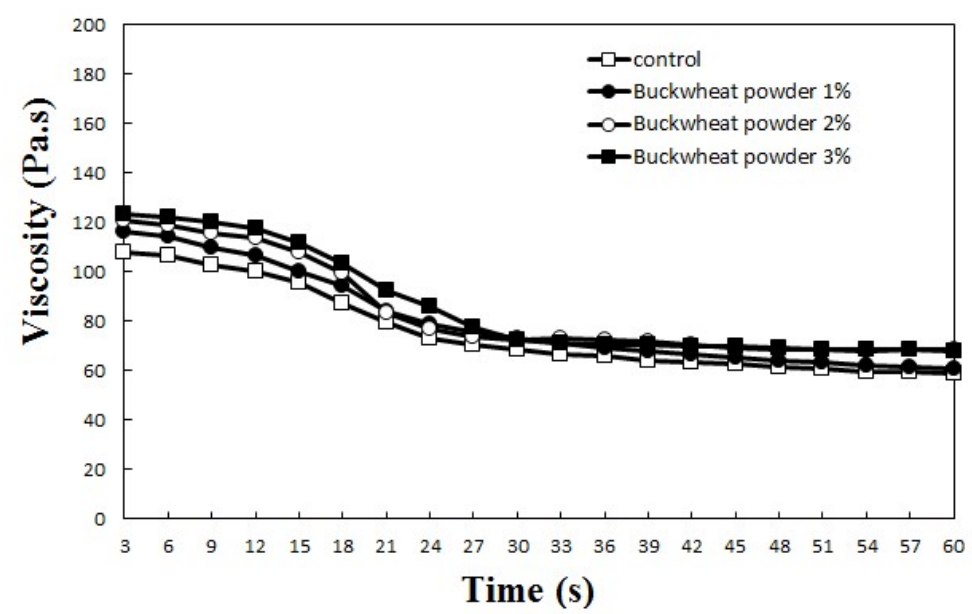

Fig. 2. Change of apparent viscosity on pork emulsion-type sausage formulated with various levels of buckwheat powder.

The relationship between the viscosity value and cooking yield of the meat batters prepared with various levels buckwheat powder is presented in Fig. 3. The viscosity value increased with increasing cooking yield in the batter $\left(\mathrm{r}^{2}=0.7283\right)$ i.e. the correlation coefficient between the two measurements was high and positive. Kim et al. (2010) found that increases in the viscosity of a meat batter was primarily affected by water binding capacity and cooking yield. Also, Shand (2000) reported that increased viscosity led to increases in cooking yield and emulsion stability. This correlation demonstrates the relationship between emulsion viscosity and emulsion stability (Aktaş and Gençcelep, 2006).

\section{TPA and sensory evaluation}

There were no significant differences in the texture profiles among the treated samples (Table 3). Previous studies found similar trendy result that the addition of dietary fiber, especially insoluble fiber, led to increases in the hardness of meat products (García et al., 2002; Steenblock et al., 2001). This result might be due to the formation of insoluble 3-dimensional structure in emulsion-type meat products, originated from insoluble fiber which has water-binding and swelling ability (Backers and Noli, 1997).

The panel detected sensory changes upon the addition of buckwheat powder to the emulsion-type sausages (Table 4). The

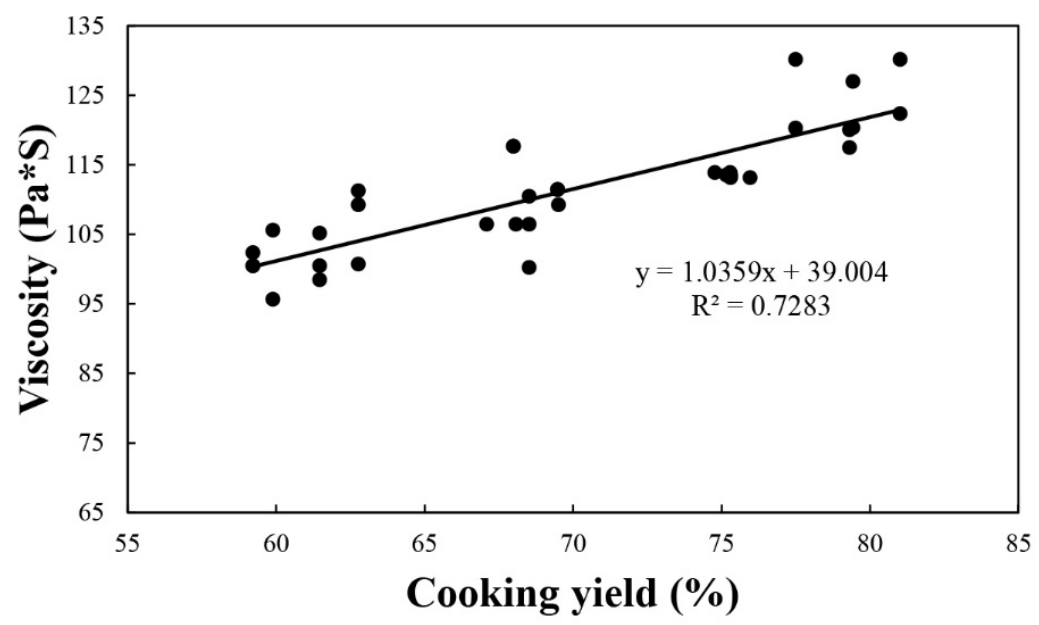

Fig. 3. Relationship between cooking yield and viscosity of meat batter formulated with various levels of buckwheat powder. 
Table 3. Texture properties of pork emulsion-type sausage formulated with various levels of buckwheat powder

\begin{tabular}{lcccc}
\hline & & \multicolumn{3}{c}{ Buckwheat powder (\%) } \\
\cline { 2 - 5 } Traits & 0 (control) & 1 & 2 & 3 \\
Hardness $(\mathrm{kg})$ & $3.60 \pm 0.31$ & $3.76 \pm 0.44$ & $3.82 \pm 0.36$ & $4.15 \pm 0.67$ \\
Springiness & $0.88 \pm 0.08$ & $0.92 \pm 0.01$ & $0.92 \pm 0.01$ & $0.93 \pm 0.02$ \\
Cohesiveness & $0.42 \pm 0.07$ & $0.43 \pm 0.06$ & $0.36 \pm 0.12$ & $0.33 \pm 0.17$ \\
Gumminess $(\mathrm{kg})$ & $1.52 \pm 0.69$ & $1.56 \pm 0.26$ & $1.25 \pm 0.25$ & $1.28 \pm 0.57$ \\
Chewiness $(\mathrm{kg})$ & $1.34 \pm 0.64$ & $1.43 \pm 0.24$ & $1.15 \pm 0.23$ & $1.17 \pm 0.53$ \\
\hline
\end{tabular}

All values are mean $\pm \mathrm{SD}$.

Table 4. Sensory properties of pork emulsion-type sausage formulated with various levels of buckwheat powder

\begin{tabular}{lcccc}
\hline \multirow{2}{*}{ Traits } & \multicolumn{3}{c}{ Buckwheat powder (\%) } \\
\cline { 2 - 5 } & 0 (control) & 1 & 2 & 3 \\
Color & $8.20 \pm 0.27^{\mathrm{b}}$ & $8.45 \pm 0.37^{\mathrm{b}}$ & $9.10 \pm 0.42^{\mathrm{a}}$ & $9.40 \pm 0.42^{\mathrm{a}}$ \\
Flavor & $7.75 \pm 0.50^{\mathrm{c}}$ & $8.40 \pm 0.42^{\mathrm{b}}$ & $8.96 \pm 0.29^{\mathrm{a}}$ & $9.35 \pm 0.42^{\mathrm{a}}$ \\
Tenderness & $9.54 \pm 0.51^{\mathrm{a}}$ & $8.74 \pm 0.69^{\mathrm{b}}$ & $8.16 \pm 0.13^{\mathrm{c}}$ & $8.08 \pm 0.52^{\mathrm{c}}$ \\
Juiciness & $8.16 \pm 0.79^{\mathrm{b}}$ & $8.32 \pm 0.31^{\mathrm{ab}}$ & $8.70 \pm 0.65^{\mathrm{ab}}$ & $9.10 \pm 0.53^{\mathrm{a}}$ \\
Overall acceptability & $8.30 \pm 0.42^{\mathrm{c}}$ & $8.85 \pm 0.46^{\mathrm{bc}}$ & $9.17 \pm 0.30^{\mathrm{b}}$ & $9.54 \pm 0.44^{\mathrm{a}}$ \\
\hline
\end{tabular}

All values are mean $\pm \mathrm{SD}$.

Sensory scores were assessed on 10 - point scale base on ( $1=$ extremely undesirable, $10=$ extremely desirable).

${ }^{\mathrm{a}-\mathrm{c}}$ Means in the same row with different letters are significantly different $(\mathrm{p}<0.05)$.

additions of $2 \%$ or $3 \%$ buckwheat powder resulted in higher $(\mathrm{p}<0.05)$ color and flavor scores, but lower tenderness scores compared to the other samples. Panel detected the significant difference in tenderness between control and treated samples with buckwheat powder, exhibiting numerical difference in instrumental tenderness. The sausages with $3 \%$ buckwheat powder had the highest $(\mathrm{p}<0.05)$ juiciness and overall acceptability scores among the treated samples.

\section{Conclusion}

The results of this study demonstrate the application of buckwheat powder in emulsion-type sausages as exhibiting enhancement in physicochemical properties such as moisture retention, cooking yield, and viscosity and sensory traits. Especially, the addition of 3\% buckwheat powder in emulsion-type sausage showed stable emulsion formation with a lower fat content and similar sensory property compared to no-added buckwheat counterpart. Therefore, the addition of buckwheat powder at level of up to $3 \%$ in emulsion-type should induce beneficial effect on quality property.

\section{Acknowledgements}

This work was supported by the research grant of the Kongju National University in 2018.

\section{References}

Aktaş N, Gençcelep H. 2006. Effect of starch type and its modifications on physicochemical properties of bologna-type 
sausage produced with sheep tail fat. Meat Sci 74:404-408.

AOAC. 2012. Official methods of analysis of AOAC International. $19^{\text {th }}$ ed. AOAC International. Gathersburg, MD, USA. p 931.

Backers T, Noli B. 1997. Dietary fibers meat processing. Int Food Market Technol 12:4-8.

Baumgertel A, Grimm R, Eisenbeiss W, Kreis W. 2003. Purification and characterization of a flavonol 3-O-betaheterodisaccharidase from the dried herb of Fagopyrum esculentum Moench. Phytochemistry 64:411-418.

Bejosano FP, Corke H. 1998. Amaranthus and buckwheat protein concentrate effects on an emulsion-type meat product. Meat Sci 50:343-353.

Choe JH, Kim HY, Han DJ, Kim YJ, Park JH, Ham YK, Kim CJ. 2011. Effect of goldenrod (Solidago virgaurea) leaf and stem powder on physical and sensory characteristics of emulsion-type sausages. Korean J Food Sci An 31:668-675.

Choe JH, Kim HY, Lee JM, Kim YJ, Kim CJ. 2013. Quality of frankfurter-type sausages with added pig skin and wheat fiber mixture as fat replacers. Meat Sci 93:849-854.

Choy AL, Morrison PD, Hughes JG, Marriott PJ, Small DM. 2013. Quality and antioxidant properties of instant noodles enhanced with common buckwheat flour. J Cereal Sci 57:281-287.

Cofrades S, Guerra MA, Carballo J, Fernández-Martín F, Jiménez-Colmenero F. 2000. Plasma protein and soy fiber content effect on bologna sausage properties as influenced by fat level. J Food Sci 65:281-287.

García ML, Domínguez R, Galvez MD, Casas C, Selgas MD. 2002. Utilization of cereal and fruit fibers in low fat dry fermented sausages. Meat Sci 60:227-236.

Johnson IT, Southgate DAT 1994. Dietary fibre and related substance. Chapman \& Hall, London, UK. pp 39-65.

Kim CS, Kim HY. 2017. Physicochemical properties of emulsion-type sausage added red yeast rice powder. Korean J Food Sci Technol 49:396-400.

Kim DW. 2013. Quality characteristic of sausage added red yeast rice. Korean J Food Preserv 20:805-809.

Kim HW, Choi JH, Choi YS, Han DJ, Kim HY, Lee MA, Shim SY, Kim CJ. 2009. Effects of wheat fiber and isolated soy protein on the quality characteristics of frankfurter-type sausages. Korean J Food Sci An 29:475-481.

Kim HY, Kim ES, Jeong JY, Choi JH, Choi YS, Han DJ, Lee MA, Kim SY, Kim CJ. 2010. Effect of bamboo salt on the physicochemical properties of meat emulsion systems. Meat Sci 86:960-965.

Lairon D, Arnault N, Bertrais S, Planells R, Clero E, Hercberg S, Boutron-Ruault MC. 2005. Dietary fiber intake and risk factors for cardiovascular disease in French adults. Am J Clin Nutr 82:1185-1194.

Lee MA, Han DJ, Choi JH, Choi YS, Kim HY, Jeong JY, Paik HD, Kim CJ. 2008. Effect of hot air dried kimchi powder on the quality characteristics of low-fat sausage. Korean J Food Sci An 28:146-153.

Lee MH, Woo SJ, Oh SK, Kwon TB. 1995. Changes in contents and composition of insoluble dietary fiber during buckwheat germination. Korean J Food Nutr 8:23-31.

Lee MS, Shon KH. 1994. Content comparison on dietary fiber and rutin of Korean buckwheat according to growing district and classification. Korean J Soc Food Sci 10:249-253.

Lin LY, Liu HM, Yu YW, Lin SD, Mau JL. 2009. Quality and antioxidant property of buckwheat enhanced wheat bread. Food Chem 112:987-991.

Mansour EH, Khalil AH. 1997. Characteristics of low-fat beef burgers as influenced by various types of wheat fibers. Food Res Int 30:199-205.

Olmedilla-Alonso B, Jiménez-Colmenero F, Sánchez-Muniz FJ. 2013. Development and assessment of healthy properties of 
meat and meat products designed as functional foods. Meat Sci 95:919-930.

Park SY, Kim HY. 2016. Effect of black rice powder levels on quality properties of emulsion-type sausage. Korean J Food Sci An 36:737-743.

Pereira MA, O'Reilly E, Augustsson K, Fraser GE, Goldbourt U, Heitmann BL, Hallmans G, Knekt P, Liu S, Pietinen P, Spiegelman D, Stevens J, Virtamo J, Willett WC, Ascherio A. 2004. Dietary fiber and risk of coronary heart disease: A pooled analysis of cohort studies. Arch Intern Med 164:370-376.

Shand PJ. 2000. Textural, water holding, and sensory properties of low-fat pork bologna with normal and waxy starch hullless barley. J Food Sci 65:101-107.

Shin HB, Kim HY, Chun JY. 2017. Quality characteristics of emulsion-type chicken sausages added different level of buckwheat powder. Korean J Poult Sci 44:135-141.

Steenblock RL, Sebranek JG, Olson DG, Love JA. 2001. The effects of oat fiber on the properties of light bologna and fatfree frankfurters. J Food Sci 66:1409-1415.

Sun YH. 2008. Health concern, food choice motives, and attitudes toward healthy eating: The mediating role of food choice motives. Appetite 51:42-49.

Utama DT, Jeong H, Kim J, Lee SK. 2018. Formula optimization of a perilla-canola oil (O/W) emulsion and its potential application as an animal fat replacer in meat emulsion. Korean J Food Sci An 38:580-592. 